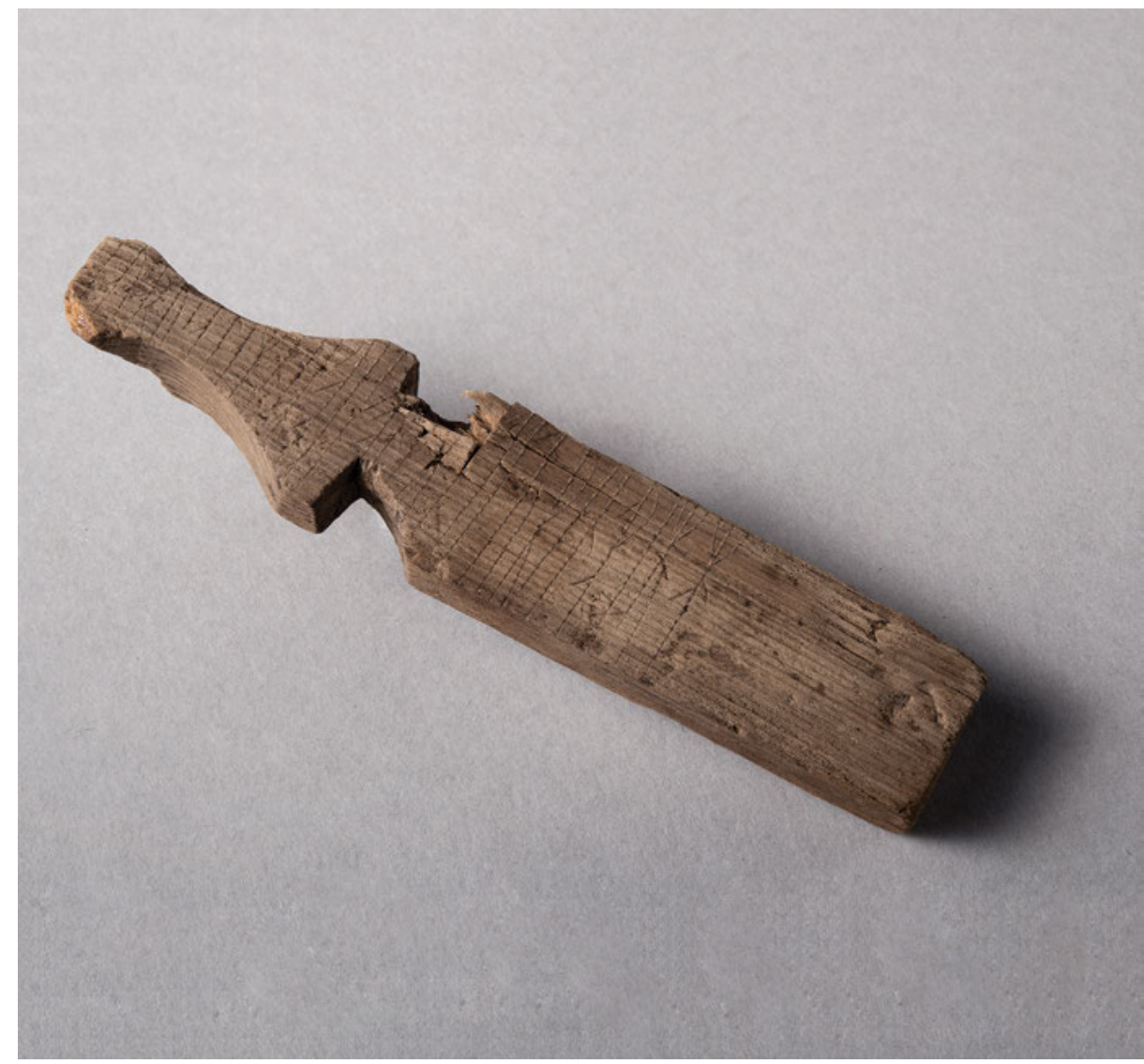

Fig. 2.1: Wooden stick with runic inscription mentioning Jerusalem [iaurrusalem], thirteenth century. Excavated from Trondheim city centre 1973-1985. NTNU, Vitenskapsmuseet, Trondheim.

D Open Access. (C) 2021 Kristin B. Aavitsland, published by De Gruyter. (c) BY-NC-ND This work is licensed under the Creative Commons Attribution-NonCommercial-NoDerivatives 4.0 International License.

https://doi.org/10.1515/9783110639438-003 


\section{Chapter 2 \\ Re-Naming Jerusalem: A Note on Associative Etymology in the Vernacular North}

As is the case with several cities and places that they came in contact with, the Norsemen had their own name for Jerusalem: Jórsalir, sometimes expanded and amplified to Jórsalaborg "the city of Jerusalem" or Jórsalaland "the land of Jerusalem," that is, "the Holy Land.” This chapter is a brief survey of the name's etymology and possible connotations in the Old Norse world.

At first glance, the Old Norse (ON) name Jórsalir may look like a purely phonetic adaptation of one of the Medieval Latin forms of the city's name, Ierusalem: ${ }^{1}$ Jorr- corresponds to Ieru- and -salir to -salem. Even though phonetic resemblance is one aspect of the Old Norse re-naming process, a closer inspection of the name Jórsalir reveals that each part of it carries several layers of meaning. What becomes clear is that the Norsemen, by naming the city Jórsalir, on the one hand made it more familiar to them by assimilating it to names for other important places in the North, like Jórvík and Uppsalir, and on the other hand gave the city a most appropriate name in accordance with its function as a centre of Christianity: I will argue that the name Jorsalir may be translated as "the city of the king." This brings the Old Norse name in line with the concept of Jerusalem as "the city of the great king," which is attested already in Ps 48(47):3, and is referred to by Jesus in the Sermon on the Mount. ${ }^{2}$

We do not know when the name Jórsalir came into being, but it must have been in the tenth century at the latest, when the Norsemen were introduced to Christianity. In the case of such an important city as Jerusalem, it is conceivable that the name is a little older. It is first attested in skaldic verse from the second half of the eleventh century, ${ }^{3}$ as well as in Swedish runic inscriptions from more or less the same

1 Besides Ierusalem and Hierusalem (with the aspirate), also the Greek form Hierosolyma was used in Medieval Latin, but the ON name is clearly based on the first form.

2 "But I say to you not to swear at all, neither by heaven for it is the throne of God: Nor by the earth, for it is his footstool: nor by Jerusalem, for it is the city of the great king," Matt 5:34-35.

3 In Stúfr the Blind Thordarson's Stúfsdrápa, st. 2, composed in memory of King Harald Hardruler [harðráði] (d. 1066), where the king is said to have gone "from Greece to lay under him Jerusalem" [und sik leggja . . . Jórsali or Grikkjum,] a clear exaggeration (cf. SkP II:352). Other early citations include Markús Skeggjason's Eiríksdrápa (ca. 1104), st. 26, which relates that the Danish King Erik "set out to explore the settlement of Jerusalem” (gerði for út at kanna . . . byggð Jórsala; SkP II:455), and Einarr Skúlason's Sigurðardrápa I, st. 4, where it is said that King Sigurd the Crusader "went to visit

Klaus Johan Myrvoll, Professor of Nordic Linguistics, University of Stavanger, Norway 
period. ${ }^{4}$ On the surface, the name is easily analysable: the first part, Jór-, is familiar from the name of another important city for the Norsemen, i.e. Jórvík in England (today's York, which, in fact, is a continuation of the ON form), whereas the second part, -salir, is widespread in Scandinavian place names, but is especially linked to the name Uppsalir, the old centre for pagan cult and royal power in Sweden (today's Uppsala). It is also found, in the singular -salr, in the territorial name Skiringssalr in Vestfold, where the far-ranging market place Kaupangr was situated.

How, then, should we understand the name Jórsalir, in its constituent parts and as a whole? Easiest to explain is the last part, -salir, plural of the ON masc. noun salr, which is an old Germanic word for 'building, house consisting of one room'. Especially in the plural, it may in Old Norse carry the more general meaning 'abode, home; farm' ${ }^{6}$ It corresponds etymologically to German Saal and Dutch zaal, which have acquired a more specialized meaning 'large hall'. In Old Norse, the word salr is mostly restricted to eddic and skaldic poetry, where one may be confronted with a scene taking place, e.g., i Óðins sali 'in the halls of Óðinn', i.e. in Valhöll (Eirm 2, 3). By contrast, the word salr is sparsely recorded in ON prose texts, ${ }^{7}$ of which the earliest are from the 1120s, and it is reasonable to assume that the word had disappeared from the spoken language before that. When the word re-appears in the modern Scandinavian languages (Norw., Sw., Dan. sal), it is a loanword from German, and it is then only used in the more restricted sense 'large hall'.

In the case of Jórsalir, we must assume that the second part, -salir, was intended to mean something beyond its already established range of 'farm' to 'village', namely

the settlement of Jerusalem" (fór vitja . . . Jórsala byggðar; SkP II:540). For these kings' expeditions to Jerusalem, see Chapter 6 (Pål Berg Svenungsen), 105-31, Chapter 8 (Lukas Raupp), 140-65 and Chapter 11 (Denys Pringle), 198-217 in this book.

4 The name is found in the inscriptions on two runestones from Uppland, both dated to the mideleventh century, in the nom.-acc. form iursalir in U 136, and in the gen.-form (til) jursala in $U$ 605; the first element in both probably resembles Old Swedish Iūr-, corresponding to ON Jór- (for the inscriptions, see SRI 6:202-203, and SRI 8:4-10). It is also found in an inscription on a whetstone from Gotland ( $G$ 216), there in the Old Gutnish form iaursalik, together with other place names such as islat $=\bar{I}$ sland, "Iceland" and serklat $=$ Serkland, "the Muslim areas." This inscription is dated to 1050-1100 (Otto von Friesen, "Runinskriften från Timans i Roma," Arkiv för nordisk filologi 56 (1942); SRI 2:238). There is a historical point to add to these datings: After Jerusalem had been captured by the Turkish Seljuks in 1073, and up to the First Crusade in 1099, it was difficult for pilgrims to get access to the city. This implies that the runic inscriptions mentioning pilgrimage to Jerusalem which are from the eleventh century are most likely older than the year 1073.

5 Harald Bjorvand and Fredrik Otto Lindeman, Våre arveord. Etymologisk ordbok, third ed. (Oslo: Novus forlag, 2019), s.v. sal.

6 Lex.poet., s.v. salr; NSL, s.v. sal.

7 The word is found several times in Snorri Sturluson's handbook in skaldic poetry, the Edda, but its use, related to stories about the pagan gods, is clearly based on poetic examples. According to ONP, the word is found outside the Edda only once in each of Ynglinga saga (in Heimskringla) and the translated sagas Karlamagnúss saga and Barlaams saga ok Josafats. 
'city'. Historically, cities often have grown out of farms or villages, and the same is true for many designations for 'city', e.g. Norwegian and Danish by (originally 'farm', ON býr, bœer), and Russian górod (cognate to Eng. yard and Norw. gard 'farm'). Probably, the name Uppsalir served as a model for Jórsalir: it is widely held among onomasts that several places in both Sweden and Norway are named after this important cultic centre, ${ }^{8}$ which had developed into a town in the Viking Age at the latest.

What then about the first part of Jórsalir? I have already mentioned the model of Jórvík, but there is a more obvious connection to a name closer to Jerusalem, i.e. the ON name for the river Jordan, which should be normalized Jórdán, not *Jórðán as it is represented in some sources. ${ }^{9}$ The name Jórdán is found even earlier than Jórsalir in the Nordic sources, in Sigvatr skáld's Erfidrápa about St Olav from around $1040 .^{10}$ There, Christ is called Jórdânar gramr, "king of the Jordan."11 The ON Jórdán is of course a more or less accurate phonetic adaptation of the Latin rendering of the

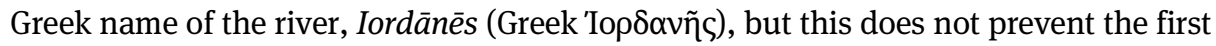
element from being associated with the name element Jór-, as is evident in both Jórvík and Jórsalir. (The second element of ON Jórdán is more difficult to explain other than as a phonetic rendering of the original. $)^{12}$ Since Jordan was one of the important goals for pilgrims in the Holy Land, it is probable that the name of this river

8 SOL, s.v. Uppsala.

9 E.g. Finnur Jónsson, "Fremmede ords behandling i oldnordisk digtning," in Festskrift til Vilhelm Thomsen fra disciple udgivet $i$ anledning af hans femogtyveårige doktorjubilæum 23 marts 1869-23 marts 1894 (Copenhagen: Gyldendalske Boghandels Forlag, 1894), 209; Lex.poet, s.v. Jórðán; SkP I:697, II:353, 477f., III:850 whereas Johan Fritzner, Ordbog over Det gamle norske Sprog, second ed., 3 vols. (Kristiania: Den norske Forlagsforening, 1886-1896), II:241 has the correct normalization Jórdán. That Jórdán is the correct $\mathrm{ON}$ form of the name may be seen from the spellings in the earliest extant Old Icelandic manuscripts, where the name is consistently written with 〈d〉, whereas 〈p〉 would be expected if the underlying form were ^Jórðán (examples from the mss. Rímbegla and the Old Icelandic Book of Homilies, cf. Ludvig Larsson, Ordförrådet $i$ de älsta islänska handskrifterna (Lund: PH. Lindstedts Universitets-Bokhandel, 1891), 179). The correct form may likewise be deduced from skaldic rhymes such as Jórdánar: fjóra (Sigv Erfól 28, ca. 1040) and Jórdán: stóran (Ólhv Árdr 2, 1256?), where the voiced fricative $\partial$ would have had to be included in the rhyme. This implies that the name should be analysed as Jór-dán, since ${ }^{\star} r d$, unlike $r \partial$, is not a possible consonant cluster in Old Norse, and there has to be a juncture between $r$ and $d$.

10 SkP I:697.

11 Both konungr Jórsala and konungr Jórdánar (and konungr Griklands!) are among the kennings for Christ that Snorri Sturluson mentions in his Edda (Snorri Sturluson, Edda. Skáldskaparmál, 2 vols, ed. Anthony Faulkes, London: Viking Society for Northern Research / University College London, 1998, 1:76).

12 The most obvious choice would be a river-name ${ }^{\star}$ Dán, but no such name seems to exist (cf. Oluf Rygh, Norske Elvenavne (Kristiania: Cammermeyer, 1904)). A candidate could have been the river Donau, but the ON name for it is Dún (see SkP III:840), cf. "Dun heitir a. er mest [va]tn er a Europa," in Heimlýsning ok helgifræði in Hauksbók. Udgiven efter de Arnamagnæanske håndskrifter no. 371, 544 og 675, 40, samt forskellige papirshåndskrifter af Det Kongelige Nordiske Oldskrift-Selskab, ed. Finnur Jónsson, Copenhagen: Thieles Bogtrykkeri, 1892-1896, 150. 
played a role in the genesis of the name Jórsalir; in Jórdân the phonetic resemblance to the original was far greater than it was in the case Ieru-: Jór.

To establish the exact meaning of the name element Jór- in both Jórsalir and Jórdân, it will be necessary to go further into the historical background of the name Jórvík, which is more likely to be the model of the others than vice versa. That name is otherwise a good example of what may happen to a name and its meaning when it wanders from one language to another and undergoes several successive adaptations. The complex linguistic history of Britain is peculiarly relevant for such a study.

York is derived from a British (i.e. Celtic) place name, which is first attested in the Greek cartographer Ptolemy (ca. 150 AD) in the form 'Eßópakov, later in Latinized form Eburacum, Eboracum. This British name, ${ }^{\star}$ Eburācon, probably originally designated "the place abounding in yew-trees" (cf. Old Irish $i(u) b h a r$ 'yew'), or, alternatively, "the estate of Eburos (a man's name)."13 Supposedly, `Eburācon had developed phonetically into something like ${ }^{\star} E v o r o ̄ g$ by the time of the Anglian settlement in the late fifth century, ${ }^{14}$ and this was in turn associated by the new settlers with Old English (OE) efor, later (with back umlaut) eofor 'wild boar' and wic probably in the sense 'town', or possibly 'temporary dwelling, camp' (a loanword from Latin vicus 'farm; village'), thus the OE name of the city, Eoforwic, 'boar-town'. This was in turn adapted by the Scandinavian settlers to ON Jórvík, at the latest when the Scandinavian chieftains Ívarr and Halfdanr conquered York in 867.

It has been argued that the ON form Jórvík came into being by a purely phonetic development from the OE form Eoforwīc. This is not very likely for language historical reasons. ${ }^{15}$ The Norsemen must instead have re-analysed the name by employing similar words from their own language. ${ }^{16}$ The last part of the name, OE -wic, 'town', was probably identified with the homonymous ON vík, 'small bay, inlet,' even though this had no

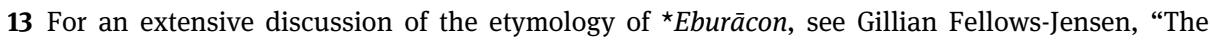
Origin and Development of the Name York," in Sources for York History to AD 1100, ed. David Rollason, et al., The Archaeology of York, vol. 1 (York: York Archaeological Trust, 1998), 226f.

14 Kenneth Jackson, Language and History in Early Britain: A Chronological Survey of the Brittonic Langauges, First to Twelfth Century A.D. (Edinburgh: University Press, 1953), 655; "Romano-British Names in the Antonine Itinerary," Britannia 1 (1970): 74; cf. Victor Watts, ed. The Cambridge Dictionary of English Place-Names (Cambridge: Cambridge University Press, 2004), s.n. York.

15 The Cambridge Dictionary of English Place-Names 2004, s.n. York, posits a development from an adapted form of Eforwic, `Éorvík, to Eórvík, Jórvík with a shift of accent from $e$ to $o$. This shift of accent, however, did not happen in Old Norse before the mid-twelfth century (see Finnur Jónsson, Norskislandske kultur- og sprogforhold i 9. og 10. årh. (Copenhagen: Andr. Fred. Høst \& Søn, 1921), 257-60), whereas the form Jórvík (two syllables) is safely attested already in the tenth-century poem Arinbjarnarkviða by Egill Skallagrímsson (Skj. A I:44, B I:38). There is similar misconceived phonetic reasoning in Eilert Ekwall, 'How Long Did the Scandinavian Language Survive in England?,' in $A$ Grammatical Miscellany Offered to Otto Jespersen on His Seventieth Birthday (Copenhagen: Levin \& Munksgaard / London: George Allen \& Unwin Ltd., 1930), 26-27, and in The Concise Oxford Dictionary of English Place-Names, 4th ed. (Oxford: Clarendon Press, 1977), s.n. York.

16 Similar reasoning by Fellows-Jensen 1998, 'The Origin and Development of the Name York:' $232 f$. 
support in the topography. ${ }^{17}$ Since the Norsemen did not possess a cognate with the Latin etymon of $\mathrm{OE} w \bar{c} c$, the meaning of the last, central part of the name thus changed from 'town' to 'small bay'. The first element, OE eofor-, 'wild boar', the Norsemen must have identified correctly as a cognate with their own word for the same animal, which at that time most likely was *jórr (stem *jór-), from Proto-Germanic *ebura- ${ }^{18}$ This stem is recorded in Old Norse in personal names only, such as Jóreiðr, Jórunn and `Jórulfr (the last one as a part of a place name). A related word, however, is jofurr, which is used in skaldic poetry in the meaning 'prince, king'. This word should also be traced back to Proto-Germanic *ebura-, like *jórr and OE eofor, and scholars have struggled to explain the exact relationship between the two ON forms, jofurr and *jorr. It will lead too far afield to go into these complicated matters here, but the most probable explanation posited so far is that the two words have originated in different case forms. ${ }^{19}$

This raises the important question about the semantic development of the word forms *jorr and jofurr. There is no doubt that Proto-Germanic *ebura- must have meant 'wild boar', and this is also the only meaning attested for its cognates in the West Germanic languages (Old English eofor, Old Saxon ebur-, Old High German ebur). Nevertheless, from the aristocratic custom of wearing helmets crowned with the figure of a wild boar, which was widespread in the Germanic area during the sixth and seventh centuries, the word came to be used for these helmets - this stage is attested for Old English - and eventually, as pars pro toto, for the warrior king himself in the poetic tradition of the North Germanic peoples. ${ }^{20}$ Behind this equation of the king with the wild boar - which is also inherent in the helmet custom - one may suggest a more immediate identification between the king and the fierce animal he hunts down.

Even though 'prince, king' is the only meaning attested for ON jofurr, it is probable that the older word *jor-/jofr-, then forming a single paradigm, could mean both 'wild boar' and 'prince, king' when Jórvík and Jórsalir got their ON names. As a tentative guess, this could have happened in the ninth century for Jórvík, and in the tenth century for Jórsalir. If this is correct, it would justify attributing the meaning "the city of the king" to Jórsalir, a most suitable name for the city where the king of all kings taught and suffered the death on the cross.

17 Fellows-Jensen, “The Origin and Development of the Name York,” 233.

18 Jan de Vries, Altnordisches etymologisches Wörterbuch, 2nd ed. (Leiden: Brill, 1962) s.v. jofurr.

19 According to this theory, the stem jor - would be the regular outcome in the nom., acc. sg. (cf. ON bjorr m. 'beaver' < Proto-Nordic *bebura-), whereas jofr- would be expected in the dat. sg. (jofri), and in the pl. (nom. jofrar, acc. jofra, dat. jofrum, gen. jofra). Secondarily, a new stem in nom.-acc. sg., jofur-, turned up through analogy (cf. Assar Janzén, "De fornvästnordiska personnamnen," in Personnamn, ed. Assar Janzén (Stockholm: Albert Bonniers Förlag / Oslo: H. Aschehoug \& Co’s Forlag / Copenhagen: J. H. Schultz Forlag: 1948), 83; Fellows-Jensen 1998, “The Origin and Development of the Name York," 232). A similar process probably underlies ON hofuð n. 'head', cf. Våre arveord. Etymologisk ordbok, s.v. hode.

20 Both IED, s.v. jofurr, and Bugge in NIæR, explain the semantic development along these lines. 
